IZA DP No. 6742

Liability-of-Foreignness Effects on Job Success of Immigrant Job Seekers

Tony Fang

Al-Karim Samnani

Milorad M. Novicevic

Mark N. Bing

July 2012 


\title{
Liability-of-Foreignness Effects on Job Success of Immigrant Job Seekers
}

\author{
Tony Fang \\ York University \\ and IZA
}

\author{
Al-Karim Samnani \\ York University
}

\author{
Milorad M. Novicevic \\ University of Mississippi \\ Mark N. Bing \\ University of Mississippi
}

\section{Discussion Paper No. 6742 \\ July 2012}

IZA
P.O. Box 7240
53072 Bonn
Germany

\author{
Phone: +49-228-3894-0 \\ Fax: +49-228-3894-180 \\ E-mail: iza@iza.org
}

\begin{abstract}
Any opinions expressed here are those of the author(s) and not those of IZA. Research published in this series may include views on policy, but the institute itself takes no institutional policy positions.

The Institute for the Study of Labor (IZA) in Bonn is a local and virtual international research center and a place of communication between science, politics and business. IZA is an independent nonprofit organization supported by Deutsche Post Foundation. The center is associated with the University of Bonn and offers a stimulating research environment through its international network, workshops and conferences, data service, project support, research visits and doctoral program. IZA engages in (i) original and internationally competitive research in all fields of labor economics, (ii) development of policy concepts, and (iii) dissemination of research results and concepts to the interested public.
\end{abstract}

IZA Discussion Papers often represent preliminary work and are circulated to encourage discussion. Citation of such a paper should account for its provisional character. A revised version may be available directly from the author. 


\section{ABSTRACT}

\section{Liability-of-Foreignness Effects on Job Success of Immigrant Job Seekers}

We examined the liability-of-foreignness (LOF) hypothesis for immigrant and native job seekers by analyzing a national dataset that tracks their use of job-search methods and their associated job outcomes in the Canadian labor market. To our knowledge this is the first empirical test of LOF at the individual-level while controlling for variables at multiple levels. We found support for LOF when job applicants used the rich media job-search methods of social networks and recruitment agencies, but not when they used the lean media of newspaper ads and the internet. Study limitations, implications, and future research are discussed.

JEL Classification: J15, J71, J78

Keywords: liability-of-foreignness, immigration policy, levels of analysis, job success, labor market

Corresponding author:

Tony Fang

School of Human Resource Management

York University

4700 Keele Street

Toronto, Ontario M3J 1P3

Canada

E-mail: tonyfang@yorku.ca

\footnotetext{
Financial support from the Social Sciences and Humanities Research Council is gratefully acknowledged as are comments from the Senior Editor of the Journal, Wayne Cascio and two anonymous referees. The authors thank Statistics Canada for granting the use of the confidential micro data. While the research and analysis are based on data from Statistics Canada, the opinions expressed do not represent the view of Statistics Canada.
} 


\section{Introduction}

The problems surrounding immigration and the labor-market outcomes of immigrants have become increasingly prominent over the past few decades. Studies have consistently found that recent immigrants continue to encounter significant barriers when searching for jobs in the labor market of their destination countries (Aydemir \& Skuterud, 2005; Frenette \& Morissette, 2005: Kahanec \& Zaiceva, 2009; Wald \& Fang, 2009). Immigrant job search is a process of selecting different search methods that immigrants use to identify job opportunities and evaluate strategies for job success in their country of immigration (Greve, Salaff, \& Chan, 2007). To gain a deeper understanding of the underlying challenges that immigrants experience with their job-search methods and to devise more targeted practices for solving these problems, scholars and policy makers have called for a more comprehensive analysis of the disadvantages that immigrants may suffer when competing against natives in the domestic labor market (Aycan \& Berry, 1996; Bloom, Grenier, \& Gunderson, 1995; Fang \& Heywood, 2010; Fang, Zikic, \& Novicevic, 2009; Grant, 1999; Miglietta \& Tartaglia, 2009; Moore \& Pacey, 2003; Picot \& Hou, 2003; Reitz, 2001; Ward \& Masgoret, 2007).

The disadvantages that immigrants encounter when competing against natives in the labor market of natives’ country of citizenship may be hypothesized to reflect immigrant "liability-of-foreignness” (i.e., LOF; Harvey, Novicevic, Buckley, \& Fung, 2005). The main assumption of this LOF hypothesis is that immigrants, facing the liability of being foreign when pursuing job opportunities in the labor market of a country that is not their own country of citizenship, will likely lack legitimacy and therefore achieve significantly lower levels of job success than natives when searching for jobs in 
the local labor market (Brekke \& Mastekaasa, 2008; Constant, Kahanec \& Zimmermann, 2009; Millar \& Choi, 2008). We test this hypothesis by examining the use of different job-search methods and the subsequent labor-market outcomes for both immigrants and natives searching for employment in the Canadian labor market. In this study, we define immigrants as individuals who were not born in Canada, but immigrated to Canada at some point during their lifetime and currently reside in Canada. We further categorize immigrant workers by the decade of their arrival. We define native-born workers as those who were born in Canada and currently reside and work in Canada.

We chose the Canadian labor market because Canada, with $18 \%$ of its population in 2009 being foreign-born, has historically attracted large migrant cohorts planning to benefit from their anticipated contributions to the country's national development. While the migrations of these cohorts were initially mostly of a humanitarian or familyreunification nature, from the 1970s to the 1990s they became primarily industrial development-oriented and were based on a planned skill/point-based system. In the mid 1990s, the skill-based system underwent a structural change as Canada made a shift in its immigration policy from attracting industrial workers to attracting knowledge workers and entrepreneurial investors. Overall, the history of different policies that have been developed to attract and support immigrants within Canada makes the context of its job market very relevant and appropriate for testing the liability-of-foreignness (LOF) hypothesis for cohorts of immigrant and native job seekers. Moreover, when compared to other national labor markets, it can be argued that the Canadian labor market is a market in which immigrants are actually very unlikely to encounter the LOF effects on their job success (Walsh, 2008). By choosing the Canadian labor market for this area of inquiry, 
we provide a conservative test of LOF effects, which, if found, provide conservative estimates of LOF's impact on immigrant job search and employment outcomes (e.g., pay satisfaction).

The main purpose of this paper is to test the LOF hypothesis by analyzing the job-search methods used and the associated job success of comparable immigrant and native workers using data available for Canadian workplaces. First, we explain the LOF hypothesis in terms of the barriers that immigrants may encounter when competing against natives in the job market of the natives' country of citizenship. Our prediction, derived from the LOF hypothesis, is that the labor-market outcomes for immigrants will be significantly less favorable than those for natives. Second, we provide a brief literature review of immigrant job-search methods to hypothesize how different methods may inflate or suppress the emergence of the LOF phenomenon. Third, we describe our sample, present our data analyses, and provide the interpretation of our results. In conclusion, we summarize our findings, outline limitations of our study, discuss policy implications, and suggest directions for future research.

\section{Liabilities-of-Foreignness and Immigrant Status}

\section{Theoretical Foundations}

The concept of foreignness is central to the field of international business (Zaheer, 1995). This concept implies that an actor who enters the host country is ascribed the outsider status of being an alien. Foreignness is a relative concept that defines these "alien” actors as foreign outsiders in relation to native (i.e., local) actors (Luo \& Mezias, 2002). This distinction is important because native actors tend to stereotype, and discriminate against, foreign actors who often encounter initial difficulties in the local social context. In turn, 
this stereotyping and discrimination may prevent foreign actors from accessing quality local opportunities (Kogan, 2006).

The natives' tendency to engage in downward comparison of others with a salient foreign identity in the local market is triggered by the foreign actors' lack of knowledge about local institutions, environment, and markets. This results from their unfamiliarity with local norms and routines that are crucial for gaining legitimacy (Joardar, Kostova, \& Ravlin, 2007; Matsuo, 2000). The need for foreign actors to develop familiarity with the local environment is supported by acculturation theory that predicts the criticality of the acculturating experience for foreign actors' success (Berry, 2003; Li, Yang, \& Yue, 2007).

Foreignness is commonly hypothesized to entail a liability that limits relative success of foreign actors in local markets. It is important to understand that liability of foreignness is a hypothesis to be tested, not an assumption to be adopted. In other words, the status of foreignness does not imply any a priori liability. In addition, foreignness is an exclusionary concept that is not specific to the country of origin (i.e., the country-oforigin effects are not relevant for the operationalization of the foreignness concept). It is more appropriate to operationalize foreignness as a categorical variable than a continuous variable. Using this operationalization, empirical tests used to determine whether foreignness entails liability effects require the act of comparing foreign and native actors (Edman, 2009; Reitz, 2001).

Foreignness has been commonly conceptualized at the organizational level (Insch \& Miller, 2005). To conceptualize the notion of foreignness at the individual-level, we engage in the practice of “concept borrowing” (Whetten, Felin, \& King, 2009: 540). 
Specifically, we engage in vertical borrowing from organizational-level to individuallevel, and in horizontal borrowing from the context of country-market entry to the context of immigrant and native job search. This borrowing across both the level and the context is performed because immigrants and natives in our study are not nested within multinational organizations. In other words, our study is not limited only to those immigrants that are employed in the multinationals that have entered the local country market.

\section{Theoretical Development}

Typically, immigrants may face two forms of liability-of-foreignness: (1) hazards of discrimination; and (2) hazards of unfamiliarity (Luo \& Mezias, 2002). One domain in which these two types of hazards are very likely to be encountered is the domain of job search (Harcourt, Lam, \& Flynn, 2008). Specifically, not only may employers prefer to employ natives over immigrants, but also immigrants may be less knowledgeable about the proper method to use for an effective job search. As a result, immigrants may be less successful than natives in the job-search process (Greve et al., 2007; Greve, Salaff, \& Chan, 2008).

The main line of research on immigrant job-search behavior stems from Chiswick (1982) who explored immigrant job search in the United States. He specifically investigated whether unemployment outcomes were affected by the imperfect transferability of immigrant human capital across national borders. Subsequent similar studies were conducted by Beggs and Chapman (1990) for the Australian labor market, Boheim and Taylor (2001) for the British labor market, and Weber and Mahringer (2002) for the Austrian labor market. Most of these studies examined how family, education, and 
immigration status could influence job-search success of unemployed immigrants and natives. Frijters, Shields, and Price (2005) examined the effectiveness of job-search methods by measuring, for example, the length of unemployment of immigrants and natives. These studies consistently found a poor level of assimilation of immigrants into the local labor market. As this lack of assimilation signals that immigrants likely face LOF, we hypothesize:

Hypothesis 1: Status as an immigrant will have a negative impact on job-market outcomes (e.g., job success) of individual immigrants.

Several studies have highlighted the significance of immigrants' familiarity with host country culture (Miglietta \& Tartaglia, 2009; Shapiro, Ozanne, \& Saatcioglu, 2008). The need to develop familiarity is an important variable of social learning theory that focuses on processes through which cultural patterns can be learned in the process of acculturation (Bandura, 1977; Berry, 2003). Based on this theory, learning to become familiar with the social context of job search will likely minimize exposure to the liabilities of being foreign in the local culture (Millar \& Choi, 2008).

When immigrants lack appropriate familiarity with the local socio-cultural context, they will have inadequate information for evaluating job-search methods used to pursue opportunities employment opportunities in their new country (Beggs \& Chapman, 1990). The various difficulties encountered when immigrants are attempting to determine whether a particular job-search method will appropriately or effectively lead to job success reflect the likelihood that their LOF interacts with the process of selecting a jobsearch method for the labor market of their new country. While immigrants will continually need to learn how to make sense of the requirements conveyed by local social 
actors, this process of improving sense-making will be more difficult to master the more that a specific job-search method requires social interactions as a medium (Daneshvary, Herzog, Hofler, \& Schlottmann, 1992). Therefore, the choice of a local job-search method may explain the difference in the job success of immigrants versus natives when immigrants are competing in the local job market. We formalize this line of argument with the following hypothesis:

Hypothesis 2: The relationship between immigrant status and individual labormarket outcomes (e.g., wages, job satisfaction, and money satisfaction) is moderated by their choice of job-search method.

Immigrant Job-search Methods and their Job Success

\section{Immigrant Job-Search Methods}

The entry of immigrants into the local labor market occurs through their use of different job-search methods (Catano, Wiesner, Hackett, \& Methot, 2005). In Canada, three particularly prevalent job-search methods (see Table 1 which is derived from the 2005 WES database used for this study) include the use of (1) social network (i.e., family or friends), (2) recruitment agency, and (3) newspaper ads and the internet. These three job-search methods taken together comprise close to $65 \%$ of the sources through which immigrants have found employment. More than $60 \%$ of the sources are used by natives to obtain employment in the Canadian labor market. It should also be noted that the relative frequency of use of each of these three job-search methods is very similar for immigrants and natives (see Table 1). Such a balance in the use of job-search methods is important for our study because our particular interest is to assess whether despite this similar use of job-search methods there are LOF effects on the job success of immigrant job seekers. 
Insert Table 1 Here

Job-search success may be defined by both positive work-related and positive psychological outcomes that result from one's job search (Rode, Arthaud-Day, Mooney, Near, \& Baldwin, 2008). The work-related outcomes reflect extrinsic job-search success. These are based on observable objective indicators. In contrast, the psychological outcomes reflect intrinsic job-search success. These are based on non-observable subjective ratings of one's attitudes toward the job (Rode et al., 2008). In this study, we examine both extrinsic (e.g., pay satisfaction) and intrinsic (e.g., job satisfaction) components of job-search success resulting from the use of different job-search methods by immigrants and natives. In the following section, we use media-richness theory to explain the dependence of the intrinsic and extrinsic components of job-search success of immigrants versus natives on their three prevalent methods of job search (social networks, recruitment agency, and newspaper ads and the internet). ${ }^{\mathrm{i}}$ We define "social networks” in this study as social ties that are not maintained in the virtual domain but rather primarily through face-to-face interactions (i.e. personal referral from a friend or family).

\section{Media-richness Theory of Immigrant Job Search}

Previous studies comparing different job-search methods in the recruitment context have used the explanatory framework of media-richness theory (for a review, see Cable \& Yu, 2006). Media-richness theory (Daft \& Lengel, 1984) posits that job-search methods vary in communicative richness from being able to provide a rich social context to being able to provide only a lean social context for job search. The socially rich methods of job search use synchronous, instant-feedback media that provide a 
communicative context rich in social cues (e.g., social networks and employment agency are the methods that use socially rich face-to-face voice communication). In contrast, the socially lean methods of job search use asynchronous, delayed-feedback media that provide a communicative context lean in social cues (e.g., newspaper ads and the internet are the methods that use socially lean paper and electronic media; Allen, Van Scoter, \& Otondo, 2004). Media-richness theory predicts that job-search methods using richer media (e.g., social networks and employment agencies), which more effectively convey social cues, will more likely contribute to the LOF effect on immigrant job search as richer media are more conducive to the emergence of stereotyping and exclusion. In contrast, the leaner media of job search (e.g., newspaper ads and the internet) will be less likely to contribute to the LOF effect on immigrant job search.

In later theoretical advancements, researchers developed perceptions of media credibility as a new dimension of media-richness theory (Cable \& Turban, 2001). This dimension reflects the extent of trust that job seekers have in a medium-specific jobsearch method (Cable \& Yu, 2006). For example, upon settling in a foreign country, immigrants tend to congregate with other immigrants from the same country of origin. Immigrant job seekers therefore are more likely to have trust in their social networks composed of persons of their own nationality as a path to equitable pay when compared to employment agencies largely containing non-immigrant or native employees, although both methods use a rich face-to-face mode of communication. Therefore, immigrant satisfaction with pay/money may not differ from native satisfaction with pay/money when jobs are obtained through the use of social networks, but it may differ and be lower than native satisfaction when jobs are obtained through employment agencies. However, 
immigrants' job satisfaction, as an indicator of the intrinsic rewards and enjoyment of a job, may be much lower than that of natives on-the-average when using social networks to find jobs because those jobs found through their social networks are not very likely to be within occupations that provide very interesting, creative, and challenging work. We formalize these hypotheses grounded in media richness and credibility theory in the following subsections of this paper for each job-search method (social networks, employment agencies, and newspaper ads/internet) while also explaining them within the context of findings from previous empirical studies.

Use of Social Networks and Job-search Success

The use of social networks as a job-search method used by immigrants has been frequently associated with immigrant enclaves (Chiswick \& Miller, 2002). Upon arriving in their new country, immigrants typically tend to settle in areas populated by other immigrants of similar ethnic backgrounds where they can develop rich communication and credible relationships (Warman, 2007). Living within immigrant enclaves may offer immigrants quick and easy access to lower-quality job. In the long term, it is also likely to produce dissatisfaction by immigrant newcomers with career prospects because of the enclaves’ adverse effects on their language proficiency (Mouw, 2003). These social networks frequently lack the presence of immigrants from prestigious occupations or from high-paying industries that offer promising career prospects. This assessment of immigrant enclaves is supported by the findings of two major empirical studies indicating that immigrants' lack of language proficiency and the inadequate quality of immigrant social networks are likely to result in a lower job satisfaction of immigrants, as compared to that of natives (Bauder, 2005; Pang, 1996). 
In the first study, Pang (1996) found a negative impact of enclave social networks on job satisfaction of young Chinese adults participating in the British labor market. Specifically, in spite of their strong professional qualifications and training, most of these young Chinese adults obtained low-quality employment in the Chinese catering industry. In the short-term, they perceived the Chinese catering industry favorably as a source of economic and social security, offering greater appeal than manual work. In the long term, however, these Chinese workers eventually became dissatisfied with jobs that offered virtually no career prospects (Pang, 1996).

The second study (Bauder, 2005) found that many South Asian immigrants in Vancouver, Canada, would seek taxi driver jobs using their ethnic network referrals. Most of them had immigrated through family reunification purposes and joined a large ethnic community of South Asian immigrants. A strong social network controlled the taxi driver niche in the local labor market. An advantage of using these social networks to obtain employment was the opportunity to bypass the recruitment and selection process. These commonly require exhibiting language proficiency, such as writing resumes, communicating by email and snail mail, and attending job interviews. However, this advantage might have been effective only for certain lower-quality niches in the labor market. This claim was grounded in the social-capital rationale which suggests that immigrant job success would be comparable to that of natives in labor-market niches but not in the broader labor market (Mouw, 2003).

Social-capital theory posits that immigrants coming from lower-quality social networks are, in the broader labor market, often subject to exclusionary practices, such as social segregation and deprivation (Harcourt et al., 2008). Scarcity of quality job 
opportunities gives an advantage to natives with stronger social capital in the form of accessible social networks. As natives typically possess a higher level of social capital than immigrants do due to their access to better job opportunities, natives are more likely to be satisfied with the success of their job search using social networks. On the other hand, immigrants are less likely to be satisfied with their jobs because they lack quality relationships not only with company insiders that hire and promote but also with mentors who are knowledgeable about the job-search process. Therefore, when immigrants and natives are hired as a result of the use of their social networks, immigrants will likely be less satisfied with their jobs as compared with natives (Heyes, 2000).

Immigrants searching for jobs in the broader labor market through social networks are also more likely to be stereotyped as less competent and less productive than natives (Borjas, 1985, 1994). As a result, their job satisfaction is likely to be lower than that of natives because their access to higher-paying jobs is often constrained by employers' exclusionary practices to screen out immigrants for these premium job opportunities. Immigrants are often less satisfied with the outcomes of their job search because they tend to be perceived as a wage-lowering competitive threat to native job seekers in the local labor market (Borjas, 2003). On a broader level, this perception might drive public support to anti-immigration policies, as well as to union practices that exclude immigrant membership (Daniels \& Von Der Ruhr, 2003). As all of these factors may jointly contribute to lower levels of job satisfaction for immigrants relative to natives as a result of using social networks to search for jobs, we hypothesize: 
Hypothesis 3: There will be a significant difference between immigrants and natives in successful job search using social networks. This difference will be particularly pronounced in the intrinsic aspect of their job success (i.e., job satisfaction).

\section{Use of Recruitment Agencies and Job-search Success}

Recruitment agencies have been a traditional method for gaining employment in a wide range of occupations of primarily an administrative and clerical nature (Peck \& Theodore, 1998). In Canada, immigrants that are recipients of welfare and unemployment insurance are commonly referred to recruitment agencies to find stable employment (for the practice in the U.S., see Houseman, 2001). Although recruitment agencies allow for a rich communication and have had, and continue to have, a role in helping immigrants to find a stable job, they are often viewed with skepticism by immigrant applicants as a credible avenue for job search (Vosko, 2000). Research has shown that these agencies have a credibility problem because they have been willing to accommodate employer requests either to not send "risky" people with accents or to send these types of "risky" applicants because of (1) the employer's ability to terminate their employment contracts more easily, (2) their lower likelihood of suing the organization following termination, and (3) their lower cost of employment (Catano et al., 2005). Although such a practice (i.e. requesting, or not requesting, “risky” applicants) would not be viewed as legal by U.S. and Canadian courts, it is not transparent and therefore seldom results in a court case. Since the recruitment agency simply works as a contractor for the employer, this practice would not absolve the employer of liability. Nevertheless, a typical outcome of such practices is that immigrants are often discriminated against because they are offered 
lower pay than natives for the same type of job (Houseman, Kalleberg, \& Erickcek, 2003; Fang \& MacPhail, 2008).

Several research studies have found support for the claim that employers increasingly use employment agencies to screen potential employees (Houseman, 2001; Kunda, Barley, \& Evans, 2002; Peck \& Theodore, 1998). The findings of these studies indicate that the use of employment agencies provides an easier method of testing immigrants for lower-paid temporary assignments. This practice allows for another way of discriminating against immigrants whose qualifications are not as well-known as those of natives. For example, Houseman et al. (2003) found that employment agencies preferred to give immigrants temporary assignments because employers considered them "risky.” As a result, a recruiter may consciously or unconsciously assess and consider a native applicant, rather than an immigrant applicant, to be more appropriate for stable employment. The outcome of this consideration is that immigrants are likely to face discrimination by being offered fewer higher-paid job opportunities, causing them to accept jobs with less satisfactory pay (Catano et al., 2005).

The threat of discrimination may represent a significant problem faced by immigrants searching for jobs through recruiting agencies because these agencies often block immigrants’ access to jobs with more equitable wages (Fang \& MacPhail, 2008; Houseman et al., 2003). Managing this threat of discrimination is a constant challenge as immigrants, compelled to use their second language during the job-search process, often lack the linguistic competence that is necessary to ensure an equitable pay relative to natives (González-Castro et al., 2009). Recently, credible evidence supporting this argument was obtained through a carefully designed field experiment (see 
Oreopoulos 2009). This field experiment provided evidence that, all qualifications being equal, job applicants with Chinese, Indian or Pakistani names were found to be forty percent less likely to be called for a job interview than were otherwise equivalent applicants with English-sounding names (eleven percent versus sixteen percent). This deficiency for immigrants in comparison to natives is especially relevant when promising job opportunities with a satisfactory pay have to be identified within an agency's offering, and their tacit and often unarticulated demands have to be interpreted, understood, and prioritized. Therefore, we hypothesize:

Hypothesis 4: There will be a significant difference between immigrants and natives in successful job search using recruitment agencies. This difference will be particularly pronounced in the extrinsic aspect of their job success (e.g., an equitable wage as satisfactory pay).

\section{Use of Newspaper Ads/the Internet and Job-search Success}

The use of newspaper ads and the internet as a job-search method provides a unique benefit to immigrants who prefer lean media and do not want to engage in social interactions such as promoting themselves in the labor market or soliciting job offers inperson. In particular, some immigrants view the process of "selling oneself” in the job market as culturally unacceptable for them. For example, Bauder (2005) found that immigrants from former Yugoslavia experienced difficulties with selling themselves as job applicants. One of the respondents described these difficulties as "We don't know how to sell ourselves.... This is totally out of our culture; you are not allowed to say something nice about yourself.” Another practice that many immigrants view as 
culturally unacceptable is the face-to-face mode of communicating rejections. Rather, most immigrants would prefer to receive a rejection through leaner media such as email or snail mail. This preference for an impersonal form of communicating rejection may be particularly salient in cases when immigrants are likely to receive multiple rejections (Feldman \& Klaas, 2002).

The applicants’ use of lean media such as newspaper ads, which represents an impersonal job-search method, has a long tradition. Moreover, applicants’ use of lean media such as the internet as a job-search method has increased considerably in many sectors of the economy since the mid-1990s (Feldman \& Klaas, 2002). The shift toward online applications has occurred because of the willingness of employers to economize in the recruitment and selection process. This approach entails hiring applicants based on more limited information about them rather than relying on an insider (applicant's family member or friend) or agency recruiter (who may likely have met with the applicant) (Cappelli, 2001). Employers may also be attracted to online applications because the digital interface would enable them to use artificial-intelligence software to screen applicants in a standardized manner. Due to its low requirement for social interactions, the internet as a method of job search may provide immigrants with a favorable lean jobsearch avenue to reduce the extent to which they are stereotyped (Kuhn \& Skuterud, 2004). In addition, immigrants that apply online are typically self-selected, a sign that they may have higher levels of computer and internet literacy (Fountain, 2005).

Immigrants who found employment using newspaper ads and the internet typically held significantly higher-quality jobs than immigrants who used employment agencies or social networks (Greve et al., 2007). A possible explanation is that these job 
seekers possess higher levels of skills and are better educated because the use of newspaper ads and the internet as job-search methods are not preferred by immigrants with lower levels of reading proficiency, writing proficiency, or computer-mediated communication. As this self-selection of immigrants will likely make them competitive relative to natives in the newspaper-posted and internet-posted job segment of the labor market, we hypothesize:

Hypothesis 5: Immigrants' job search will be as successful as that of natives when they use newspaper ads and the internet as job-search methods.

\section{Data and Method}

The data for this study were drawn from the 2005 Workplace and Employee Survey (WES), a national survey of a large number of workplaces and employees. Conducted by Statistics Canada, the WES contains linked data that includes both employer and employee components. Employers were first sampled according to their physical location after which employees were sampled within each location using employer-provided lists. The data collection was first administered in 1999, but was discontinued in 2006. The 2005 WES was the last survey in which the employee data was collected in addition to the workplace data. This 2005 WES dataset contained a sample of 24,197 employee respondents (representing an 83\% response rate), selected from 6,693 surveyed business locations in Canada. The final usable sample in this study consisted of 23,776 respondents. The business locations have been drawn from the Business Register maintained by the Business Register Division of Statistics Canada and from lists of employees provided by the surveyed employers. The Business Register is a list of all 
businesses in Canada and is updated each month using data from various surveys, business profiling, and administrative data.

The population from which the workplaces were sampled included all Canadian business locations that had paid employees in March 2005 with the exception of employers located in Yukon, Nunavut and the Northwest Territories. Also excluded were employers that operated in crop and animal production, fishing, hunting and trapping, private households, religious organizations and public administration. Prior to sample selection, the business locations were stratified into relatively homogeneous groups by industry, region and size.

The population from which the employee data were collected was based on lists of employees made available by the sampled workplaces. It included all employees who received a Customs Canada and Revenue Agency T-4 Supplementary (tax) form. Depending on the size of the workplace, a systematic random sample of three, six, nine or twelve employees per organization was drawn. For workplaces with fewer than four employees, all employees were selected. The main benefit of this differential sampling is that it results in potentially more representative occupational group coverage. Data collection was conducted by telephone interviews in Statistics Canada Regional Offices with those persons who had agreed to participate in the survey by filling out and mailing in an employee participation form.

The WES includes both native Canadian workers and immigrant workers that immigrated within the following cohorts: pre-1970, 1970-1979, 1980-1989, 1990-1999, and post-2000. The survey includes individuals 16-65 years old working throughout Canada with the exception of those working in the Yukon, Nunavut, and the Northwest 
Territories. Furthermore, also excluded are those working in the domains of agriculture; fishing; road, bridge, and highway maintenance; government services; and religious organizations. The WES contains a rich array of demographic and labor market information pertaining to individual education (attainment) and (job) training, labor, wages and salaries, as well as workplace organization, innovation, and performance of employees selected from within the sampled workplaces based on a list of employees provided by the employer. The survey has been administered annually since 1999, with the average sample of about 6,000 employers and 20,000 employees.

The survey data sampled here indicates that there have been some notable changes in the cohorts of arriving immigrants since the 1970s. First, a larger proportion of recent immigrants are minorities coming to Canada for economic or familyreunification purposes (Bloom, Grenier, \& Gunderson, 1995; Grant, 1999). Second, immigrants entering the labor market in the early 1980s and early 1990s were arriving at a time of economic recession (Bloom et al., 1995; Grant, 1999). Third, over the period of 1971 to 1991, there had been a rapid rise in natives’ education levels as compared to those of immigrants over that same time period (Reitz, 2001). Finally, the trend in lowerentry earnings has been experienced not only by immigrants, but also by native-born workers (Aydemir \& Skuterud, 2005; Frenette \& Morissette, 2005).

Descriptive Statistics

The data presented in Tables 1B, 2, 3, and 4 provide descriptive comparisons between the immigrant cohorts and Canadian natives in terms of the labor-market outcomes of these groups, broken down by the job-search method used by each group. These tables present the three prevalent job-search methods, which include an individual's use of family or 
friends as social networks (Table 2), recruitment agency (Table 3), and newspaper ads/the internet (Table 4). The occupational groups are also presented broken-down by the method through which the immigrant and native groups searched for employment. The labor-market outcomes examined include hourly wage, job satisfaction, and money/pay satisfaction, as well as the level of over-education, which is defined as an employee's actual level of educational attainment relative to the educational level that he or she perceives as required for his/her job. In other words, employees indicated their actual education level, which was compared with their response to the question: "What is the minimum level of education required for this job”.

Any interpretation of differences between immigrant and natives observed from the descriptive statistics shown in Tables 2, 3, and 4 should be made with reservation because many potentially influential variables that may affect individual labor-market outcomes are not being controlled. Nevertheless, we do control for some of these potentially influential variables such as age, gender, non-European origins, and so on, in our regression model. Keeping this limitation in mind, one interesting difference that can be observed is the level of over-education of recent immigrants (after the 1990s) compared to Canadian natives, regardless of the method by which employment was found. Another difference that can be observed is that recent immigrants are wellrepresented in professional jobs, but not in managerial positions. We single out these differences because we will refer to them later in this paper when discussing our findings derived from the regression analyses conducted to test our hypotheses related to different job success outcomes for immigrants and natives.

Insert Tables 2, 3, and 4 Here 


\section{Measures}

Wages. We measured wages based on employees' self-reports of total earnings and total hours of work. When wages of employees were self-reported in a non-hourly format (e.g., salary), these wages were converted to an hourly wage rate by dividing total compensation by total hours of work.

Job Satisfaction. A 4-point likert scale was used to measure how satisfied employees were with their current job.

Money Satisfaction. A 4-point likert scale was used to measure how satisfied employees are with their current pay.

Control Variables. Employees indicated their gender, age, non-European ethnic origin, marital status, number of children, presence of young children (6 years or younger), years of education, years of experience, union/collective bargaining coverage, job tenure, parttime status, supervision status, participation in the team, participation in training, hour of working at home, duration of last unemployment, economic regions (6), industry groups (14), and workplace size. ${ }^{\mathrm{ii}}$

Results of Regression Analyses

To test our hypotheses, we conducted regression analysis by controlling for such multiple-level variables described for the Canadian national sample sourced from the WES in order to estimate the "net” effects of job-search methods on labor-market outcomes of immigrant and native workers with comparable individual, job, and workplace characteristics. Descriptive statistics for all the variables included in the regression analysis are reported in Table $1 \mathrm{~B}$. 
We used the survey regression methods and employee survey weights provided by the WES, identifying the primary survey units as the establishments from which multiple workers may be interviewed. ${ }^{\text {iii }}$ The resulting estimation is designed to return representative results and to provide heteroskedasticity-robust standard errors. These errors correct for the common components associated with a cluster of workers from a given workplace (for more on when to use heteroskedasticity-robust standard errors, see Stock \& Watson 2003; 596-7). This survey regression method also effectively returns correct standard errors for the coefficients of aggregate variables at the workplace-level, such as industry and workplace size. In the following subsections of this paper, we use this method to analyze our sampled data and test our hypotheses about the relationships between immigrant status (immigrant/native), job-search method (social networks, recruitment agency, and newspaper ads/the internet), and job success.

\section{Findings Related to the Liability-of-Foreignness Effects on Job Success}

The results of our regression analyses of immigrant and native job success achieved from the use of different job-search methods are shown in Table 5. The results indicate the beta weights and significance levels for each of the job search. The results for the use of social networks of family and/or friends, as well as for the use of recruitment agencies, indicate that wages of immigrants are significantly lower than those of natives for the cohorts of recent (i.e., post-2000) immigrants, as well as for the cohort of immigrants that arrived in the 1990s. These two immigrant cohorts do not differ significantly in wages from natives when newspaper ads and the internet are used as the job-search methods. For immigrant cohorts from the pre-1970s, 1970s, and 1980s we found no statistically significant differences in wages between them and natives in spite 
of the fact that the sample size used for job search through social networks of family and friends, for example, was 9,582, and hence statistical power for finding differences in these cases was more than adequate.

Insert Table 5 Here

The results for job satisfaction when family and friends are used for job searches among immigrants support the claim that immigrant status has a significant influence on job success as a labor-market outcome, with immigrants experiencing less job satisfaction than natives. However, money/pay satisfaction differed only when recruitment agency was used as the job-search method (save for pre-1970s immigrants with respect to newspaper ads/internet), with immigrant cohorts of the pre-1970s, 1970s, and the 1990s experiencing less pay satisfaction than natives. Thus, for all three dependent variables of wages, job satisfaction, and pay satisfaction, there are several findings that provide support for H1; liability-of-foreignness appears to have a negative impact on the job success of immigrants in comparison to natives when controlling for important individual differences in age, education, minority status, job tenure, union membership, etc., and even for industry group and economic region.

Pre-1970s, 1970s, and 1990s immigrants were found to have lower levels of pay/money satisfaction than natives when using a recruiting agency to find employment, but this difference was not obtained when social networks (i.e., family/friends) were used to find employment. Alternatively, 1970s, 1980s, 1990s, and recent immigrants had lower levels of job satisfaction in comparison to natives when using social networks to find employment but not when recruitment agencies were used. Last, as 1990s and recent immigrants were found to have lower wages than natives when using social networks 
(i.e., family/friends) and recruiting agencies for job searches, whereas no such difference was found when newspaper ads and the internet were used. This provides support for $\mathbf{H 2}$. The choice of job search appears to moderate the relationship between immigrant status and individual labor-market outcomes (i.e., job success outcomes, such as wages and job satisfaction).

Findings about the Use of Social Networks (Family and Friends)

When obtaining employment through social networks as the job-search method, the immigrant cohorts of the 1990s as well as recent immigrants each had significantly lower levels of wages (i.e., the extrinsic component of job-search success) and job satisfaction (i.e., the intrinsic component of job-search success) as compared with natives. Additionally, the 1970s and 1980s cohorts of immigrants experienced significantly lower levels of job satisfaction when compared to natives. For money/pay satisfaction, none of the immigrant cohorts showed a statistically significant difference when compared to native Canadian workers. This finding reveals that recent immigrant cohorts experienced lower wages and lower job satisfaction than did natives but no difference for money/pay satisfaction, thus supporting H3. Except for pay satisfaction, we found significant LOF effects on the job success (i.e., wages and job satisfaction) of immigrants who searched for employment using social networks of family and friends.

As our analysis was performed using natives as a referent group for comparison, it should be noted that our results do not necessarily indicate that immigrant cohorts, when considered in isolation, were dissatisfied with their jobs or satisfied with their pay. We focus primarily on these differences in comparison to the native referent group because the main purpose of this study is to test the liability-of-foreignness hypothesis in 
relative terms by comparing the labor-market outcomes of immigrants with those of natives.

Findings about the Use of Recruitment Agencies

The results for recent immigrants compared to natives who searched for employment using the recruitment agency as a job-search method indicate that two cohorts ( $\mathrm{n}=886$ ) had significantly lower wages. These two cohorts are the 1990s immigrants and the recent post-2000 immigrants. Interestingly, among those who used recruitment agencies as a job-search method, there were no statistically significant differences between any of the immigrant and native cohorts in terms of job satisfaction. However, the immigrant cohorts of the pre-1970s, 1970s, and 1990s show significantly lower levels of money/pay satisfaction. We can infer that with respect to wages and pay satisfaction, $\mathbf{H} \mathbf{4}$ is supported by our data. Thus, for wages and pay satisfaction we found significant LOF effects on the job success of immigrants who searched for employment using recruitment agencies as the job-search method.

Findings about the Use of Newspaper Ads and the Internet

The regression results for immigrants who searched and found employment through newspaper ads and the internet show that none of the five immigrant cohorts had significantly lower wages in comparison to natives. However, the 1990s immigrant cohort had a significantly lower level of job satisfaction. The results for the money/pay satisfaction outcome $(n=4,085)$ reveal that the only immigrant cohort with statistically significant differences compared to natives is the pre-1970s cohort, which has significantly lower levels of money/pay satisfaction. Therefore, our H5 is largely supported save with two exceptions, indicating that newspaper ads and the internet may 
be viewed as job-search methods that do not entail the same degree of potential discrimination against immigrants. Moreover, this means that we found next to no LOF effects on the job success of immigrants who searched for employment using newspaper ads and the internet as their job-search methods.

\section{Discussion}

The general finding of our study is that there are liability-of-foreignness effects that decrease the job success of immigrant job seekers when they use rich media. Very often these liability-of-foreignness effects do not occur when immigrants use lean media for their job searches. For example, while the LOF effects in terms of the differences in wages for immigrants who find employment through family or friends or a recruitment agency (i.e., rich media) are significantly lower for the 1990s and recent immigrant cohorts relative to the Canadian-born workers, the differences in wages for immigrants who find employment through newspaper ads and the internet are not significant for any of the immigrant cohorts.

The effectiveness of the lean media for job search by immigrants is illustrated by the descriptive statistics shown in Table 4. These data indicate that the post-2000 immigrants had higher wages than Canadian natives and higher levels of over-education when searching for jobs through newspaper ads or the internet. However, this does not imply recommending that all immigrants should primarily use the internet as their jobsearch method. The internet may be the preferred medium for job searchers with higher levels of writing proficiency and computer literacy. While by controlling for education, we likely captured some degree of an individual's computer literacy and writing proficiency, we do not assume to have captured the breadth of these competencies. 
Specifically, it is likely that immigrants with higher skill levels, who target professional jobs, tend to avoid using their social networks or recruitment agency for job search and instead pursue employment opportunities through newspaper ads and the internet. The internet job-search method has, however, its own limitations. For example, once education and occupation variables are controlled, internet job seekers have been found to take a significantly longer period of time to obtain employment than those who do not use internet job searches as a method (Kuhn \& Skuterud, 2004).

Our findings should be interpreted taking into account the following three considerations. First, various immigrant cohorts are compared with the baseline of native workers. This lack of matching in comparison to natives is particularly apparent when comparing recent immigrants that have entered the labor market within the past decade, to natives that have, on average, entered the labor market in earlier decades. However, we believe that this limitation has been somewhat mitigated by the inclusion of control variables such as age, education level, years of experience, job tenure, and so on in our regression analysis.

The second consideration is that the sample sizes for immigrants who have found employment through a recruitment agency are perhaps below ideal levels. This is apparent when examining coefficients that show differences that might be practically meaningful, yet not statistically significant. Although the aggregate sample sizes for individuals who obtained employment through a recruitment agency are high by jobsearch method, when segregating the groups by cohorts, the sample sizes are considerably reduced, which may have harmed some degree of statistical power that is necessary to find effects. 
Finally, the third consideration is that we did not measure wages, job satisfaction, and pay satisfaction of immigrants and native Canadian individuals who have not successfully landed employment through a specific job-search method. However, this is not limitation because our theoretical interest was limited to examining only whether there were significant differences between immigrants and native Canadian individuals who were successful in using a specific job-search method to gain employment.

\section{Managerial Relevance}

Previous research on the employment impact of immigration policy has been mostly focused on the factors (e.g., economic recession, structural changes towards a point system, educational background of immigrants) influencing the ability of immigrants to assimilate into the host country labor market (Aydemir \& Skuterud, 2005; Bloom et al., 1995; Frenette \& Morissette, 2005; Grant, 1999; Moore \& Pacey, 2003; Reitz, 2001). This study adds to the body of research by identifying the factors related to job-search methods and their impact on job success of immigrants and natives. For example, we found significantly lower levels of wages for recent immigrants in comparison to natives who searched for employment through either social networks or recruitment agencies. When these two job-search methods, both using rich media, are combined, they account for almost 50\% of job-search methods used in Canada to successfully gain employment. These findings may help Canadian policy makers target these specific methods of job searches when developing their plans of action for formulating employment assistance strategies for immigrant workers.

Our finding that job satisfaction as a labor-market outcome was lower for immigrants than for natives who searched for a job through social networks can be 
partially attributed to the negative influence of immigrant enclaves and their adverse effects on immigrant language proficiency. Policy makers can address these problems by targeting immigrant enclaves through programs developed to improve language proficiency of immigrants, using more effective recruitment and marketing campaigns aimed at promoting professional and clerical jobs, while discouraging immigrants from using only immigrant enclaves as a means of finding employment (Bauder, 2005).

With respect to the use of recruitment agency as a job-search method, our results support previous findings indicating that these agencies may very well tend to stereotype and may even implicitly discriminate against immigrants. We found significantly lower levels of wages to exist for recent immigrants compared to natives who found employment through recruitment agencies. An alternative explanation is that recruitment agencies may find it difficult to assess immigrants' foreign educational and work experiences. This makes them hesitant to refer immigrant applicants to their client organizations for higher paying positions. The lack of official language proficiency (English and French) for some immigrants may compound this problem even further. Evidently, this practice of expediting the recruitment and employment process should be more closely monitored, audited, and revised to prevent discriminatory practices and to ensure more targeted job-specific hiring of immigrants.

The job-search methods using newspaper ads and the internet were found to yield the most favorable outcomes for immigrants. Only two immigrant cohorts differed from natives when using this job-search method. One immigrant cohort was lower on job satisfaction (1990s), and another was lower on pay satisfaction (pre-1970s). However, there were no differences found in wage outcomes between immigrant and native workers 
when they used the newspaper ads/internet job-search methods to obtain employment, and thus these methods do appear to yield the most preferable results for immigrants. This finding indicates that immigrants may have been able to overcome strong barriers in the local labor market by using newspaper ads/internet job-search methods in pursuit of employment. Therefore, policy-makers and HR professionals should identify related best practices in the equitable recruitment and promotion of immigrant employment opportunities.

\section{Conclusion}

Immigrants searching for jobs face many barriers that can be attributed to their liabilityof-foreignness. This form of liability is typically manifested in either local discriminatory employment practices or stereotyping the immigrants' country of national origin. The immigrants' liability of foreignness stems primarily from their unfamiliarity with the local environment and their lack of local roots to help them gain necessary legitimacy in the local labor market (Greve et al., 2008).

In our study, we examined whether individual immigrants using different jobsearch methods experience a liability-of-foreignness (LOF) relative to natives when attempting to achieve job success in the Canadian labor market. We found LOF effects on immigrants’ job success when they used rich media (social networks and employment agencies) for their job searches. We found very few LOF effects on job success of immigrants who used lean media (newspaper ads and the internet) for their job searches. These results will likely be instrumental to researchers, practitioners and policy-makers to identify best practices associated with reducing the "liability-of-outsidership” (Johanson \& Vahlne, 2009: 1411) effects on the job success of immigrant job seekers. 


\section{REFERENCES}

Allen D, Van Scoter J, Otondo, R. (2004). Recruitment communication media: Impact on pre-hire outcomes. Personnel Psychology, 57, 143-171.

Aycan Z, Berry JW. (1996). Impact of employment-related experiences in immigrants' psychological well-being and adaptation to Canada. Canadian Journal of Behavioural Science, 28, 240-251.

Aydemir A, Skuterud M. (2005). Explaining the deteriorating entry earnings of Canada's immigration cohorts: 1966-2000. Canadian Journal of Economics, 38, 641-671.

Bandura A. (1977). Social learning theory. New York: General Learning Press.

Bauder H. (2005). Attitudes towards work: Ethnic minorities and immigrant groups in Vancouver. Journal of International Migration and Integration, 6, 125-151.

Beggs J, Chapman B. (1990). Search efficiency, skill transferability and immigrant relative unemployment rates in Australia. Applied Economics, 22, 249-260.

Berry J. (2003). Conceptual approaches to acculturation. In Chun K, Organista P, Marin $\mathrm{P}$ (Eds.), Acculturation: Advances in theory, measurement, and applied research. Washington, DC: APA.

Bloom DE, Grenier G, Gunderson M. (1995). The changing labor market position of Canadian immigrants. Canadian Journal of Economics, 28, 987-1005.

Boheim R, Taylor M. (2001). Job-search methods, intensity and success in Britain in the 1990s, Working Paper no. 2001. Essex: Institute of Social and Economic Research.

Borjas GJ. (1985). Assimilation, changes in cohort quality and the earnings of immigrants. Journal of Labor Economics, 3, 463-489.

Borjas GJ. (1994). The economics of immigration. Journal of Economic Literature, 32, 1667-1717.

Borjas GJ. (2003). The labor demand curve is downward sloping: Reexamining the impact of immigration on the labor market. Quarterly Journal of Economics, 118, 1335-1374.

Brekke I, Mastekaasa A. (2008). Highly educated immigrants in the Norwegian labour market: Permanent disadvantage? Work, Employment and Society, 22, 507-526. 
Cable D, Turban D. (2001). Recruitment image equity: Establishing the dimensions, sources, and value of job seekers’ organizational beliefs. In Ferris G (Ed.), Research in personnel and human resources management, 20, 115-163.

Cable, D., \& Yu, R. 2006. Managing job seekers’ organizational image beliefs: The role of media richness and media credibility. Journal of Applied Psychology, 91(4): 828-840.

Cappelli, P., 2001. Making the most of on-line recruiting,” Harvard Business Review, Vol. 79, pp 139-146.

Catano VM, Wiesner WH, Hackett RD, Methot LL. (2005). Recruitment and selection in Canada (3rd edition). Toronto, ON: Nelson.

Chen G, Bliese P, Mathieu J. (2005). Conceptual framework and statistical procedures for delineating and testing multilevel theories of homology. Organizational Research Methods, 8, 375-409.

Chiswick BR. (1982). The employment of immigrants in the United States. In Fellner W (Ed.), Contemporary Economic Problems 1982: 1-37. Washington, DC: American Enterprise Institute.

Chiswick BR, Miller PW. (2002). Immigrant earnings: Language skills, linguistic concentrations and the business cycle. Journal of Population Economics, 15, 3157.

Constant A, Kahanec M, Zimmermann K. (2009). Attitudes towards immigrants, other integration barriers, and their veracity. International Journal of Manpower, 30, 5-19.

Daft R, Lengel R. (1984). Information richness: A new approach to managerial behavior and organizational design. In Cummings L, Staw B (Eds.), Research in organizational behavior, 6: 191-233. Homewood, IL: JAI Press.

Daneshvary N, Herzog H Jr, Hofler H, Schlottmann A. (1992). Job search and immigrant assimilation: An earnings frontier approach. Review of Economics and Statistics, 74, 482-492.

Daniels JP, Von Der Ruhr M. (2003). The determinants of immigration-policy preferences in advanced economies: A cross country study. Atlantic Economic Journal, 11, 146-158.

Edman J. (2009). Unpacking foreignness: A literature review and suggestions for expanding current research. Paper presented at the Annual AOM Meeting, Chicago, IL. 
Fang T, Heywood J. (2010). Immigration, ethnic differentials and output pay in Canada. British Journal of Industrial Relations, 48, 109-130.

Fang T, MacPhail F. (2008). Transitions from temporary to permanent work in Canada: Who makes the transition and why. Social Indicators Research, 88, 51-74.

Fang T, Zikic J, Novicevic M. (2009). Career success of immigrant professionals: Stock and flow of their career capital, International Journal of Manpower, 30, 472-488.

Feldman DC, Klaas BS. (2002). Internet job hunting: a field study of applicant experiences with online recruiting. Human Resource Management, 41, 175-192.

Fountain C. (2005). Finding a job in the internet age. Social Forces, 83, 1235-1262.

Frenette M., Morissette R. (2005). Will they ever converge? Earnings of immigrant and Canadian-born workers over the last two decades. International Migration Review, 39, 228-258.

Frijters P, Shields MA, Price SW. (2005). Job search methods and their success: A comparison of immigrants and natives in the UK. Economic Journal, Royal Economic Society, 115, F359-F376, November.

González-Castro JL, Ubillos S and Ibáñez J. (2009). Predictive factors of ethnic prejudice toward immigrants in a representative subsample of Spanish young people. Journal of Applied Social Psychology, 39, 1690-1717.

Grant M. (1999). Evidence of new immigrant assimilation in Canada. Canadian Journal of Economics, 32, 930-955.

Greve A, Salaff JW, Chan E. (2007). Immigrants and the job search: Comparing the internet to other paths to jobs: 12b. Paper presented at 40th Annual Hawaii International Conference on System Sciences (HICSS'07).

Greve A, Salaff JW, Chan E. (2008). Immigrants and job search: An institutional perspective. Proceedings of the $13^{\text {th }}$ International ITA Workshop, Krakow, Poland: 88-108.

Harcourt M, Lam H, Flynn M. (2008). Discrimination in hiring against immigrants and ethnic minorities: The effect of unionization. International Journal of Human Resource Management, 19, 98-115.

Harvey M, Novicevic M, Buckley M, Fung H. (2005). Reducing inpatriate liability of foreignness by addressing stigmatization and stereotype threats. Journal of World Business, 40, 267-280. 
Heyes JE. (2000). Race-related differences in promotions and support: Underlying effect of human and social capital. Organization Science, 11, 493-508.

Houseman SN. (2001). Why employers use flexible staffing arrangements: Evidence from an establishment survey. Industrial and Labor Relations Review, 55, 149170 .

Houseman SN, Kalleberg AL, Erickcek GA. (2003). The role of temporary employment in tight labor markets. Industrial and Labor Relations Review, 57, 105-127.

Insch G, Miller S. (2005). Perception of foreignness: Benefit or liability? Journal of Managerial Issues, 18, 423-438.

Joardar A, Kostova T, Ravlin E. (2007). An experimental study of the acceptance of a foreign newcomer into a workgroup. Journal of International Management, 13, 513-537.

Johanson J, Vahlne J. (2009). The Uppsala internationalization process model revisited: From liability of foreignness to liability of outsidership. Journal of International Business Studies, 40, 1411-1431.

Kahanec M, Zaiceva A. (2009). Labor market outcomes of immigrants and non-citizens in the EU: An East-West comparison. International Journal of Manpower, 30, 97-113.

Kogan I. (2006). Labor markets and economic incorporation among recent immigrants in Europe. Social Forces, 85, 697-721.

Kuhn P, Skuterud M. (2004). Internet job search and unemployment durations. American Economic Review, 94, 218-232.

Kunda G, Barley S, Evans J. (2002). Why do contractors contract? The theory and reality of high-end contingent labor. Industrial and Labor Relations Review, 55, 234-261.

Luo Y, Mezias J. (2002). Liability of foreignness: Concepts, constructs, and consequences. Journal of International Management, 8, 283-300.

Li J, Yang J, Yue D. (2007). Identity, community and audience: How wholly owned subsidiaries gain legitimacy in China. Academy of Management Journal, 59, 175-190.

Matsuo H. (2000). Liability of foreignness and the uses of expatriates in Japanese multinational corporations in the United States. Sociological Inquiry, 70, 88-106. 
Miglietta A, Tartaglia S. (2009). The influence of the length of stay, linguistic competence and media exposure in immigrants' adaptation. Cross-Cultural Research, 43, 46-61.

Millar CCJM, Choi CJ. (2008). Worker identity, the liability of foreignness, the exclusion of local managers and unionism: A conceptual analysis. Journal of Organizational Change Management, 21, 460-470.

Moore EG., Pacey MA. (2003). Changing income inequality and immigration in Canada, 1980-1995. Canadian Public Policy/Analyse de Politiques, 29, 33-52.

Mouw T. (2003). Social capital and finding a job: Do contacts matter? American Sociological Review, 68, 868-898.

Oreopoulos, Philip. 2009. Why do skilled immigrants struggle in the labour market? A field experiment with sixty thousand résumés.” Working Paper no. 09-03. Vancouver: Metropolis British Columbia.

Pang M. (1996). Barriers perceived by young Chinese adults to their employment in companies in the UK. International Journal of Human Resource Management, 7, 889-902.

Peck J, Theodore N. (1998). The business of contingent work: Growth and restructuring in Chicago's temporary employment industry. Work, Employment and Society, 12, 655-674.

Picot G, Hou F. (2003). The rise in low income rates among immigrants in Canada. Analytical Studies Research Paper Series, Catalogue 11F0019MIF \# 198: 61.

Reitz JG. (2001). Immigrant skill utilization in the Canadian labor market: Implications of human capital research. Journal of International Migration and Integration, 2, 347-378.

Rode JC, Arthaud-Day ML, Mooney CH, Near JP, Baldwin TT. (2008). Ability and personality predictors of salary, perceived job, and perceived career success in the initial career stage. International Journal of Selection and Assessment, 16, 292-299.

Shapiro JM, Ozanne JL, Saatcioglu B. (2008). An interpretive examination of the development of cultural sensitivity in international business. Journal of International Business Studies, 39, 71-87.

Stock JH, Watson MW. (2003). Introduction to Econometrics. Boston, MA: Pearson Educational Publishing. 
Sutton R, Staw B. (1995). The practice of theory borrowing in organizational studies: Current issues and future directions. Administrative Science Quarterly, 40, 371384.

Vosko LF. (2000). Temporary work: The gendered rise of a precarious eemployment rrelationship. Toronto: University Press.

Wald S, Fang T. (2009). Overeducated immigrants in the Canadian labour market: Evidence from the Workplace and Employee Survey. Canadian Public Policy, 34, 457-479.

Walsh J. (2008). Navigating globalization: Immigration policy in Canada and Australia, 1945-2007. Sociological Forum, 23, 786-813.

Ward C, Masgoret A-M. (2007). Immigrant entry into the workforce: A research note from New Zealand. International Journal of Intercultural Relations, 31, 525530 .

Warman C. (2007). Ethnic enclaves and immigrant earnings growth. Canadian Journal of Economics, 40, 401-422.

Weber A, Mahringer H. (2002). Choice and success of job search methods. Working Paper no. 125 (Economics Series). Vienna: Institute for Advanced Studies.

Whetten D, Felin T, King B. (2009). The practice of theory borrowing in organizational studies: Current issues and future directions. Journal of Management, 36, 537563.

Zaheer S. (1995). The practice of theory borrowing in organizational studies: Current issues and future directions. Academy of Management Journal, 38, 341-363. 
Table 1A. Employee Sources of Job Search by Immigrant Status: Canadian Labor Market in 2005 - Workplace and Employee Survey (WES)

\begin{tabular}{|c|c|c|}
\hline & Immigrants (\%) & Natives (\%) \\
\hline $\begin{array}{l}\text { Help wanted ad } \\
\text { http://www.statcan.ca/english/freepub/71- } \\
\text { 221-XIE/tE0F30.htm -LEARN_1 }\end{array}$ & 13.7 & 15.0 \\
\hline $\begin{array}{l}\text { Family or friend } \\
\text { http://www.statcan.ca/english/freepub/71- } \\
\text { 221-XIE/tE0F30.htm -LEARN_2 }\end{array}$ & 42.1 & 39.7 \\
\hline $\begin{array}{l}\text { Union posting } \\
\text { http://www.statcan.ca/english/freepub/71- } \\
\text { 221-XIE/tE0F30.htm -LEARN_3 }\end{array}$ & 0.92 & 0.64 \\
\hline $\begin{array}{l}\text { Canada Employment Centre/Other } \\
\text { government agency } \\
\text { http://www.statcan.ca/english/freepub/71- } \\
\text { 221-XIE/tE0F30.htm -LEARN_4 }\end{array}$ & 2.92 & 2.97 \\
\hline $\begin{array}{l}\text { On-campus recruitment } \\
\text { http://www.statcan.ca/english/freepub/71- } \\
\text { 221-XIE/tE0F30.htm -LEARN_5 }\end{array}$ & 2.48 & 2.55 \\
\hline $\begin{array}{l}\text { News story } \\
\text { http://www.statcan.ca/english/freepub/71- } \\
\text { 221-XIE/tE0F30.htm -LEARN_6 } \\
\end{array}$ & 2.90 & 1.82 \\
\hline $\begin{array}{l}\text { Job fair } \\
\text { http://www.statcan.ca/english/freepub/71- } \\
\text { 221-XIE/tE0F30.htm -LEARN_7 }\end{array}$ & 0.62 & 0.39 \\
\hline $\begin{array}{l}\text { Recruitment agency (headhunter) } \\
\text { http://www.statcan.ca/english/freepub/71- } \\
\text { 221-XIE/tE0F30.htm -LEARN_ }\end{array}$ & 4.52 & 2.52 \\
\hline $\begin{array}{l}\text { Personal initiative } \\
\text { http://www.statcan.ca/english/freepub/71- } \\
\text { 221-XIE/tE0F30.htm -LEARN_9 } \\
\end{array}$ & 22.2 & 21.6 \\
\hline $\begin{array}{l}\text { Directly recruited by current employer } \\
\text { http://www.statcan.ca/english/freepub/71- } \\
\text { 221-XIE/tE0F30.htm LEARN_10 }\end{array}$ & 13.2 & 14.7 \\
\hline $\begin{array}{l}\text { Internet } \\
\text { http://www.statcan.ca/english/freepub/71- } \\
\text { 221-XIE/tE0F30.htm -LEARN_11 }\end{array}$ & 4.87 & 3.30 \\
\hline Other & 7.57 & 9.11 \\
\hline Number of Observations & 3,803 & 19,973 \\
\hline
\end{tabular}




\begin{tabular}{|l|c|}
\hline Table 1B. Summary Statistics \\
\hline Variable & Mean (SD) \\
\hline & \\
\hline Natural Logarithm of hourly wage & $2.95(0.526)$ \\
\hline Job satisfaction & $3.23(0.655)$ \\
\hline Money satisfaction & $2.92(0.729)$ \\
\hline & $0.820(0.384)$ \\
\hline [Non-immigrants] & $0.033(0.179)$ \\
\hline Immigrants who arrived before 70s & $0.041(0.199)$ \\
\hline Immigrants who arrived in the 70s & $0.040(0.197)$ \\
\hline Immigrants who arrived in the 80s & $0.046(0.210)$ \\
\hline Immigrants who arrived in the 90s & $0.019(0.135)$ \\
\hline Recent immigrants who arrived after the 90s & \\
\hline & $0.228(0.420)$ \\
\hline Non-Europeans & $0.523(0.499)$ \\
\hline Female & $40.9(11.4)$ \\
\hline Age in years & $0.536(0.499)$ \\
\hline Married (1 if married, 0 otherwise) & $13.45(2.33)$ \\
\hline Years of education & $0.394(0.489)$ \\
\hline Dependent children & $0.154(0.361)$ \\
\hline Presence of young children & \\
\hline & $0.147(0.354)$ \\
\hline Part-time & \\
\hline Supervision (supervision of other employees' work \\
on a day-to-day basis)
\end{tabular}

Note: Also included are dummy variables identifying 6 regions and 14 industries. Standard deviations of the means are in parentheses. 
Table 2. Job Outcomes by Search Methods (by immigrant status and period of immigration) - Social Networks of Family and Friends

\begin{tabular}{|c|c|c|c|c|c|c|c|}
\hline $\begin{array}{l}\text { Job-search } \\
\text { Method: Family } \\
\text { or friend }\end{array}$ & $\begin{array}{l}\text { Canadian } \\
\text {-born }\end{array}$ & $\begin{array}{l}\text { All } \\
\text { immigrants }\end{array}$ & $\begin{array}{l}\text { (Came to } \\
\text { Canada...) } \\
\text { Pre-1970 } \\
\end{array}$ & $\begin{array}{l}1970- \\
1979\end{array}$ & $\begin{array}{l}1980- \\
1989\end{array}$ & $\begin{array}{l}1990- \\
1999\end{array}$ & $\begin{array}{l}\text { Recent } \\
\text { immigrants } \\
\text { (post-2000) }\end{array}$ \\
\hline Hourly Wage & 20.92 & 20.11 & 24.25 & 23.18 & 19.54 & 16.75 & 15.72 \\
\hline Job Satisfaction & 3.27 & 3.11 & 3.18 & 3.10 & 3.06 & 3.09 & 3.07 \\
\hline $\begin{array}{l}\text { Money } \\
\text { Satisfaction }\end{array}$ & 2.96 & 2.89 & 2.94 & 2.94 & 2.84 & 2.90 & 2.79 \\
\hline $\begin{array}{l}\text { Percent over- } \\
\text { educated }\end{array}$ & 0.372 & 0.456 & 0.314 & 0.431 & 0.535 & 0.487 & 0.456 \\
\hline $\begin{array}{l}\text { Years of over- } \\
\text { education }\end{array}$ & 1.54 & 2.05 & 1.49 & 1.65 & 2.33 & 2.39 & 2.48 \\
\hline Sample size & 8,052 & 1,530 & 308 & 339 & 342 & 411 & 130 \\
\hline
\end{tabular}

\begin{tabular}{|l|c|c|c|c|c|c|c|}
\hline Occupation & & & & & & & \\
\hline & & & & & & & \\
\hline Managers & 10.30 & 10.60 & 19.58 & 10.38 & 12.23 & 6.71 & 2.63 \\
\hline Professionals & 12.70 & 15.60 & 11.84 & 17.33 & 12.75 & 16.57 & 21.46 \\
\hline Technical/trades & 46.15 & 45.24 & 40.62 & 50.82 & 46.57 & 43.26 & 42.14 \\
\hline Marketing/sales & 7.61 & 6.27 & 7.35 & 3.00 & 6.07 & 7.87 & 8.46 \\
\hline Clerical/admin & 15.11 & 13.00 & 16.37 & 14.11 & 11.45 & 12.60 & 8.91 \\
\hline Production & 8.12 & 9.28 & 4.24 & 4.36 & 10.94 & 13.01 & 16.39 \\
\hline
\end{tabular}

Note: Job and money satisfaction were measured on 4-point Likert-type scale with 1 as "very dissatisfied," 2 as "dissatisfied," 3 as "satisfied," and 4 as "very satisfied." The numbers for the various occupations (e.g., Managers, Professionals, etc.) in the table are percentages. 
Table 3. Job Outcomes by Search Methods (by immigrant status and period of immigration) - Recruitment Agency

\begin{tabular}{|c|c|c|c|c|c|c|c|}
\hline $\begin{array}{l}\text { Job-search } \\
\text { Method: } \\
\text { Recruitment } \\
\text { agency }\end{array}$ & $\begin{array}{l}\text { Canadian } \\
\text {-born }\end{array}$ & $\begin{array}{l}\text { All } \\
\text { immigrants }\end{array}$ & $\begin{array}{l}\text { (Came to } \\
\text { Canada...) } \\
\text { Pre-1970 }\end{array}$ & $\begin{array}{l}1970- \\
1979\end{array}$ & $\begin{array}{l}1980- \\
1989\end{array}$ & $\begin{array}{l}1990- \\
1999\end{array}$ & $\begin{array}{l}\text { Recent } \\
\text { immigrants } \\
\text { (post-2000) }\end{array}$ \\
\hline Hourly Wage & 30.57 & 27.31 & 26.66 & 35.06 & 28.48 & 22.52 & 23.48 \\
\hline Job Satisfaction & 3.39 & 3.21 & 3.17 & 3.44 & 3.32 & 3.09 & 3.01 \\
\hline $\begin{array}{l}\text { Money } \\
\text { Satisfaction }\end{array}$ & 3.09 & 2.79 & 2.62 & 2.81 & 2.92 & 2.77 & 2.88 \\
\hline $\begin{array}{l}\text { Percent over- } \\
\text { educated }\end{array}$ & 0.216 & 0.330 & 0.067 & 0.147 & 0.383 & 0.476 & 0.589 \\
\hline $\begin{array}{l}\text { Years of over- } \\
\text { education }\end{array}$ & 0.92 & 0.14 & 0.31 & 0.55 & 2.14 & 2.23 & 1.88 \\
\hline Sample size & 659 & 227 & 32 & 52 & 55 & 59 & 29 \\
\hline
\end{tabular}

\begin{tabular}{|l|c|c|c|c|c|c|c|}
\hline Occupation & & & & & & & \\
\hline & & & & & & & \\
\hline Managers & 23.28 & 18.98 & 11.60 & 39.44 & 12.27 & 19.50 & 2.56 \\
\hline Professionals & 21.36 & 28.06 & 30.73 & 27.77 & 28.40 & 21.96 & 34.53 \\
\hline Technical/trades & 28.97 & 29.58 & 16.42 & 17.16 & 29.66 & 40.42 & 43.63 \\
\hline Marketing/sales & 0.49 & 0.18 & 0.49 & 0 & 0.40 & 0 & 0.23 \\
\hline Clerical/admin & 24.50 & 19.40 & 39.42 & 14.30 & 22.52 & 13.53 & 12.82 \\
\hline Production & 1.40 & 3.80 & 1.34 & 1.33 & 6.75 & 4.58 & 6.23 \\
\hline
\end{tabular}

Note: Job and money satisfaction were measured on 4-point Likert-type scale with 1 as "very dissatisfied," 2 as "dissatisfied," 3 as "satisfied,” and 4 as "very satisfied.” The numbers for the various occupations (e.g., Managers, Professionals, etc.) in the table are percentages. 
Table 4. Job Outcomes by Search Methods (by immigrant status and period of immigration) - Newspaper Ads/Internet

\begin{tabular}{|c|c|c|c|c|c|c|c|}
\hline $\begin{array}{l}\text { Job-search } \\
\text { Method: } \\
\text { Newspaper } \\
\text { Ads/Internet }\end{array}$ & $\begin{array}{l}\text { Canadian } \\
\text {-born }\end{array}$ & $\begin{array}{l}\text { All } \\
\text { immigrants }\end{array}$ & $\begin{array}{l}\text { (Came to } \\
\text { Canada...) } \\
\text { Pre-1970 }\end{array}$ & $\begin{array}{l}1970- \\
1979\end{array}$ & $\begin{array}{l}1980- \\
1989\end{array}$ & $\begin{array}{l}1990- \\
1999\end{array}$ & $\begin{array}{l}\text { Recent } \\
\text { immigrants } \\
\text { (post-2000) }\end{array}$ \\
\hline Hourly Wage & 21.36 & 22.90 & 26.75 & 24.12 & 22.25 & 20.86 & 22.08 \\
\hline Job Satisfaction & 3.22 & 3.15 & 3.22 & 3.18 & 3.20 & 3.06 & 3.09 \\
\hline $\begin{array}{l}\text { Money } \\
\text { Satisfaction }\end{array}$ & 2.91 & 2.80 & 2.65 & 2.78 & 2.90 & 2.81 & 2.75 \\
\hline $\begin{array}{l}\text { Percent over- } \\
\text { educated }\end{array}$ & 0.338 & 0.430 & 0.375 & 0.207 & 0.445 & 0.512 & 0.722 \\
\hline $\begin{array}{l}\text { Years of over- } \\
\text { education }\end{array}$ & 1.43 & 1.85 & 1.02 & 1.07 & 1.79 & 2.29 & 3.59 \\
\hline Sample size & 3,333 & 753 & 129 & 153 & 175 & 200 & 96 \\
\hline
\end{tabular}

\begin{tabular}{|l|c|c|c|c|c|c|c|}
\hline Occupation & & & & & & & \\
\hline & & & & & & & \\
\hline Managers & 11.25 & 9.54 & 6.86 & 7.61 & 15.24 & 10.65 & 1.21 \\
\hline Professionals & 19.37 & 27.80 & 21.84 & 30.51 & 23.15 & 30.09 & 34.40 \\
\hline Technical/trades & 36.60 & 36.24 & 44.74 & 33.03 & 41.38 & 29.17 & 38.02 \\
\hline Marketing/sales & 8.58 & 5.18 & 6.19 & 2.80 & 2.46 & 11.42 & 0 \\
\hline Clerical/admin & 18.39 & 17.69 & 20.20 & 21.70 & 11.85 & 16.55 & 22.25 \\
\hline Production & 5.81 & 3.55 & 0.17 & 4.35 & 5.91 & 2.12 & 4.11 \\
\hline
\end{tabular}

Note: Job and money satisfaction were measured on 4-point Likert-type scale with 1 as "very dissatisfied," 2 as "dissatisfied," 3 as "satisfied," and 4 as "very satisfied." The numbers for the various occupations (e.g., Managers, Professionals, etc.) in the table are percentages. 
Table 5. Results of Regression Analyses (Immigrant status was coded as a 1 and native status as a 0 for all regression analyses)

\begin{tabular}{|l|c|c|c|}
\hline Immigrant Cohort - Wages & Family/Friends & Recruitment Agency & $\begin{array}{c}\text { Newspaper } \\
\text { Ads/Internet }\end{array}$ \\
\hline & Beta (t) & Beta (t) & Beta (t) \\
\hline Pre-1970s & $0.037(0.69)$ & $-0.181(-1.52)$ & $0.046(0.84)$ \\
\hline $1970 s$ & $0.031(0.83)$ & $-0.084(-1.11)$ & $-0.039(-0.66)$ \\
\hline $1980 s$ & $0.001(0.02)$ & $-0.131(-1.55)$ & $0.014(0.19)$ \\
\hline $1990 s$ & $-0.123^{* *}(-3.10)$ & $-0.331^{* *}(-3.84)$ & $-0.058(-1.11)$ \\
\hline Recent Immigrants & $-0.153^{* * *}(-2.57)$ & $-0.364^{*}(-2.47)$ & $-0.030(-0.30)$ \\
\hline$N$ & 9,582 & 886 & 4,086 \\
\hline$R^{2}$ & 0.49 & 0.58 & 0.55 \\
\hline
\end{tabular}

\begin{tabular}{|l|c|c|c|}
\hline $\begin{array}{l}\text { Immigrant Cohort - Job } \\
\text { Satisfaction }\end{array}$ & Family/Friends & Recruitment Agency & $\begin{array}{c}\text { Newspaper } \\
\text { Ads/Internet }\end{array}$ \\
\hline & Beta $(\mathrm{t})$ & Beta $(\mathrm{t})$ & Beta (t) \\
\hline Pre-1970s & $-0.111(-1.39)$ & $-0.106(-0.76)$ & $-0.024(-0.26)$ \\
\hline $1970 s$ & $-0.120^{*}(-2.04)$ & $0.015(0.13)$ & $-0.061(-0.61)$ \\
\hline $1980 s$ & $-0.164^{*}(-2.05)$ & $-0.167(-1.14)$ & $-0.022(-0.19)$ \\
\hline $1990 s$ & $-0.146 *(-2.08)$ & $-0.227(-1.37)$ & $-0.156^{* *}(-2.63)$ \\
\hline Recent Immigrants & $-0.155(-1.73)$ & $-0.212(-1.46)$ & $-0.122(-0.98)$ \\
\hline$N$ & 9,568 & 884 & 4,079 \\
\hline$R^{2}$ & 0.06 & 0.21 & 0.09 \\
\hline
\end{tabular}

\begin{tabular}{|l|c|c|c|}
\hline $\begin{array}{l}\text { Immigrant Cohort - Money } \\
\text { Satisfaction }\end{array}$ & Family/Friends & Recruitment Agency & $\begin{array}{c}\text { Newspaper } \\
\text { Ads/Internet }\end{array}$ \\
\hline & Beta $(\mathrm{t})$ & Beta $(\mathrm{t})$ & Beta (t) \\
\hline Pre-1970s & $-0.005(-0.05)$ & $-0.305(-1.90)$ & $-0.239(-1.90)$ \\
\hline $1970 s$ & $0.014(0.22)$ & $-0.366(-1.94)$ & $-0.109(-0.91)$ \\
\hline $1980 s$ & $-0.080(-0.89)$ & $-0.271(-1.42)$ & $0.027(0.29)$ \\
\hline $1990 s$ & $-0.002(-0.03)$ & $-0.306(-1.99)$ & $-0.048(-0.55)$ \\
\hline Recent Immigrants & $-0.121(-1.14)$ & $-0.175(-0.89)$ & $0.119(-1.21)$ \\
\hline$N$ & 9,572 & 885 & 4,085 \\
\hline$R^{2}$ & 0.04 & 0.18 & 0.07 \\
\hline
\end{tabular}




\section{ENDNOTES}

${ }^{\mathrm{i}}$ Newspaper ads and the internet were combined into one category of job search because they both fall into the "lean media" category in comparison to social networks of friends and family and recruiting agencies.

ii By controlling for gender, age, minority status, marital status, years of education, years of experience, union/collective bargaining coverage, job tenure, and part-time status in our analyses, we have narrowed the cause of differences found between immigrants and natives in terms of wages and job success to possibilities of discrimination, and thus to LOF, rather than to differences in job qualifications and other factors (e.g., industry and economic region), although such alternative causes could not be eliminated entirely.

iii All estimations are done in Stata 9 using the "survey" commands and identifying the underlying establishments as the primary survey units. This automatically generates robust standard errors while the survey weights return consistent point estimates. 